\title{
Female Genital Mutilation/Cutting: A Conceptual Discussion
}

\author{
Darlene Mwende Ndasi \\ School of Arts and Humanities, Edith Cowan University, \\ Western Australia \\ Kwadwo Adusei-Asante \\ School of Arts and Humanities, Edith Cowan University, \\ Western Australia
}

\begin{abstract}
Female genital mutilation/cutting (FGM/C) is a dangerous practice that predates all religions and is perpetrated on children for reasons in various cultural and global contexts, causing adverse lifelong health consequences, including sexual, physical and psychological issues, for survivors. Even so, there appears to be no documented work that brings together the major conceptual blocks on FGM/C; a gap this paper begins to fill. This paper summarises major concepts on $\mathrm{FGM} / \mathrm{C}$ as a resource and evaluates key evidence on the practice. While the practice of FGM/C is highly concentrated in Africa, it has spread globally, with a shift towards medicalisation among migrant communities and in traditional settings. $A$ focus of this paper is to propagate awareness and polarise debates, to bring to an end the practice of FGM/C globally.
\end{abstract}

Keywords: female genital cutting, FGM/C, gender, women

\section{INTRODUCTION}

The term female genital cutting (FGC) was coined by Jane Hosken (1979), and came into use in the early 1980s; before this time, the phrase 'female genital circumcision' was widely used (Rushwan, 2013). Female genital mutilation and cutting (FGM/C) was formally adopted in 1991 by the World Health Organization (WHO) at the conference of the Inter-African Committee on Traditional Practices Affecting the Health of Women and Children, in Addis Ababa, Ethiopia. As the term female circumcision is used by proponents of the practice, the adoption of the term FGM/C by the WHO represented an oppositional stand against the practice, and demonstrated the seriousness and severity of the procedure to the health of women and girls (Rushwan, 2013). However, the term female genital mutilation is highly controversial-some African women assert that they are not mutilated and find the term offensive and inflammatory (Horowitz \& Jackson, 1997).

The literature relevant to FGM/C research is diverse, and the definitions are structured in both the contexts of those who support or practice the ritual and those who oppose and view it as the sexual mutilation of women and girls, as well as a violation of their human and sexual rights (Mitike \& Deressa, 2009). Further, it has been argued that the documented definition of FGM/C reflects the Western perspective of the practice, and contains no contribution by the communities who practice the ritual (Smith, 2011). Sheldon and Wilkininson (1998) and Essén and Johnsdotter (2004) reported that although female genital cosmetic surgeries (FGCS) such as labiaplasty and vaginal augmentation, which are purported to beautify the genitalia and amplify female sexuality, are viewed as different from FGM/C, the procedures are similar, with the only difference being the social setting and cultures in which these occur. 
Like FGM/C, FGCS refer to various non-medical genital corrective surgeries (Abdulcadir, Irion, \& de Tejada, 2015) including clitoridectomy, G-spot augmentation, hymenoplasty (Shaw et al., 2013) and perinioplasty (Gonzales-Alabastro, Eilber, Anger, \& Berman, 2019). However, it is important to note that consent is a key aspect in the context of both FGCS and FGM/C. In the Western economies where FGCS is commonly performed on adults (Johansen, Ziyada, ShellDuncan, Kaplan, \& Leye, 2018), consent is always sought, as opposed to FGM/C, which is performed on children who cannot consent to the procedure, and thus, it is constrained to parental authority (Kimani \& Shell-Duncan, 2018).

Essén and Johnsdotter (2004), Sheldon and Wilkinson (1998) and Smith (2011) argued that attitudes towards FGCS are biased against FGM/C, and that Western imperialism is the basis for why these practices are considered different, when in fact, they are the same thing occurring in different cultures and contexts. Sheldon and Wilkinson (1998) further argued that the social pressures on women in ethnic societies to conform to patriarchal social norms such as FGM/C are not different from their counterparts in Western society in relation to FGCS. Berer (2007) argued that FGCS is similar to FGM/C and warrants prosecution as does FGM/C.

\section{DEFINITIONS AND TERMINOLOGIES OF FGM/C}

According to the WHO, FGM/C comprises 'all procedures that involve partial or total removal of the external female genitalia or other injury to the female genital organs for non-medical reasons' (WHO, 1997, p. 3, 2018). FGM/C is usually performed on children between 0-15 years old (Zurynski et al., 2017); traditionally, at 8 years of age on average. However, FGM/C can occur at any age. Kolawale (2011) argued that FGM/C is infused with cultural, legal and medical implications, rendering it difficult to adequately define. Controversial debates regarding the terminology and its definition continue across all societies, social groups and cultures. Almroth, Elmusharaf, et al. (2005) pointed to concerns among scholars about the use of the terminology and the rituals of FGM/C, noting that some scholars claim that 'mutilation' (p. 457) is a medically acceptable term as it involves the removal of healthy tissue and organs without medical indication. Further, several authors have argued that the term has negative connotations and denotes negative attitudes towards the procedure, and may be offensive to some cultural groups (Almroth \& Elmusharaf, 2007; Almroth, Elmusharaf, et al., 2005a \& b).

The term 'female circumcision' implies an analogy with male circumcision, which is misleading from an anatomical aspect as male circumcision only involves the removal of the glans, which by no means corresponds to the cutting of female genitalia (Almroth, Elmusharaf, et al., 2005). Critics have argued that FGM/C cannot be compared with male circumcision, unless this were to imply the penis is completely amputated and the surrounding tissue removed, as the cutting experienced by girls is extremely severe with irreversible effects that inhibit both sexual and reproductive capacities (Kolawole, 2011). Despite the history of FGM/C, there is no consensus on what the ritual should be called (Kolawole, 2011); however, Cook, Dickens and Fathalla (2002) argued that the term female genital cutting has been widely used to implement 'valueneutral language', with the objective of adequately describing the nature of the procedure.

Bibbings (2006) stated that 'female genital mutilation' suggests torture and violent bodily injury forced on children and unwilling women by men and women from their cultural groups for the benefit of men and their communities or groups. This viewpoint is strongly shared by this study, and both the terms female genital mutilation and cutting (FGM/C) have been used concurrently to take a strong stand against the procedure, while acknowledging its cultural, social and health implications. 


\section{WHY DOES FGM/C OCCUR?}

$\mathrm{FGM} / \mathrm{C}$ is one of the many practices that are imposed on women, and has been suggested to be a strategy that exploits female sexuality for the sexual pleasure of men (Abusharaf, 2006; Hilber et al., 2012; Rahman \& Toubia, 2001). Various authors have postulated that marriage (Rahman \& Toubia, 2001), religion (Leval, Widmark, Tishelman, \& Maina Ahlberg, 2004), culture (Jones, Ehiri, \& Anyanwu, 2004), ethnicity (Idowu, 2008), maternalism (Berggren, Salam, Bergström, Johansson, \& Edberg, 2004), patriarchy and social pressures (Abusharaf, 2006) operate to support the continuance of this procedure. Additionally, community attitudes towards the continuance of the practice are reported to slow and frustrate measures designed to address and potentially end it (Livermore, Monteiro, \& Rymer, 2007; Newland, 2006).

Barstow (1999) argued that FGM/C was practiced by early pharaohs as a custom that served as a principle measure of legitimacy for all claims of 'kingship' (p. 502), and was also adopted by the wealthy and the powerful in relation to inheritance and legal matters. Further, FGM/C was considered a measure by men of their wives' fidelity (as is the case among African tribes and communities), to prevent women from enjoying intercourse, consequently reducing the possibility of adultery in women and to distinguish 'honourable' women from prostitutes (Barstow, 1999, p. 505). Indeed, Davis (2010) suggested that infibulation was a form of female sexual castration intended to prevent female slaves from reproducing. Further, Lightfoot-Klein (1989) suggested that the nature of polygamous relationships among tribal and ethnic peoples perpetuated FGM/C, as a means to control women's sexuality by preventing them from enjoying sex and consequently reducing the possibility of adultery.

\section{Marriage}

In communities that practice FGM/C, it is thought that the procedure increases marriageability (Fahmy, El-Mouelhy, \& Ragab, 2010; Varol, Turkmani, Black, Hall, \& Dawson, 2015)—women who have undergone the procedure are highly valued by their families, with communities validating the gender roles of a mother and wife (Rahman \& Toubia, 2001). It has been reported that men in communities that practice FGM/C would not marry a woman who is not 'cut' (Gruenbaum, 2006). This is reflected in bride price negotiations, where there is no need for discussions regarding $\mathrm{FGM} / \mathrm{C}$, as there is an expectation that any girl presented for marriage must have undergone the procedure (Gruenbaum, 2006; Jones et al., 2004). Further, it has been suggested that FGM/C is performed as a rite of passage in some ethnic groups, and allows girls to transition from childhood into womanhood and facilitating marriage, which reportedly occurs between the ages of 9-15 years old (Fahmy et al., 2010).

The social pressure from older women and the wider community ensures that younger women allow FGM/C to be practiced on their daughters (Mackie \& LeJeune, 2009). It is believed that accepting FGM/C assists them to avoid ostracisation by the community and improves the prospects of their daughter finding wealthier husbands, given that the bride price is higher for women with FGM/C (Mackie, 2000). Those women who have come of age and are not 'cut' face social sanctions within their family and community, diminishing their chances of marriage and jeopardising their social status and livelihood (Njue \& Askew, 2004b). Gruenbaum (2001) provided another insight into the motivations behind the practice of FGM/C, stating that there is a belief that to become a 'real woman' (p. 27), one must be physically altered, which includes genital alteration, thereby complementing gender roles and social status in the community. In fact, Nussbaum (1999) argued that women without FGM/C are seen as highly sexualised, and the procedure is enforced as a measure to curb infidelity (Toubia, 1994). Indeed, Rahman and Toubia (2001) argued that FGM/C aims to reduce female sex desire so that a husband can take more wives, consequently serving the sexual interests of men. 


\section{Religion}

In many traditional African communities, the practice of FGM/C is attributed to religion, with a large proportion of women believing that their religion requires FGM/C to be carried out (UNICEF, 2005). Additionally, it has been reported that in some Islamic communities, the practice is a requirement of Sharia law, although this is not recorded anywhere in the Quran (Leval et al., 2004). In countries where the practice is prevalent, it has been reported that a large segment-for example, 70\% of women in Mali, 57\% in Mauritania and 33\% in Egyptbelieve that FGM/C is a religious requirement that ensures virginity (UNICEF, 2005). It has also been reported that in some communities in Sub-Saharan Africa, it is believed that removing a girl's clitoris provides her with religious purity and spiritual cleanliness (WHO, 2009). Although different religious groups, including Muslims, Jews and Christians, cite FGM/C as a requirement, there is no literature that supports such claims in any of these religions, and the relationship between FGM/C and religion has not been substantiated (Porterfield, 2006).

\section{Ethnicity and socio-cultural factors}

Fahmy et al. (2010) argued that patriarchal social structures in FGM/C-prevalent communities play key roles in supporting and enforcing male dominance over the sexuality and reproductive rights of women. In Sub-Saharan Africa, every community group is recognised by their cultural practices and customs, and different types of FGM/C can be attributed to different community/ethnic groups, usually known as tribes (Jones et al., 2004). Within certain groups, female children are socialised to understand the implications of having unmodified genitals; for example, that the clitoris can grow to the same length as a penis between the legs of a woman and cause the death of a man if the clitoris touches his penis, and therefore, the clitoris must be excised (Idowu, 2008). Additionally, among the Maasai, a woman cannot be called a mother even when she bears children if she is not genitally cut (Boyle \& Corl, 2010); Shell-Duncan (2001) observed that in other ethnic communities, women who are not genitally cut cannot attend funerals. Among the Abagusii, FGM/C marks the acquisition of social status, such that girls aged between 9-15 years old are then seen as ready for marriage, allowing negotiations for a bride price to occur and arranged marriages to follow soon after (Njue \& Askew, 2004b).

Gibeau (1998) argued that FGM/C provides clarification of roles and cultural and social cohesion, and is a source of pride for the communities that practice the procedure; thus, any effort to undermine or eradicate the procedure should be understood to stem from ethnocentrism and cultural imposition. In Kenya, for example, FGM/C was arguably practiced in defiance to the imposition of Western civilisation by the British (Thomas, 2000). In addition, Boyle and Corl (2010) suggested that the campaign against FGM/C by Europeans was seen as a ruse by the communities that practiced it, so that Europeans could marry local women and take their land. Silverman (2004) supported this claim, arguing that Western anthropologists adopt pluralist and relativist positions instead of defending FGM/C eradication efforts.

Shell-Duncan (2001) highlighted that FGM/C is supported by tribal and political leaders, frustrating efforts by the international community to end the practice. For example, Kenya's first president, Mzee Jomo Kenyatta (1938), affirmed that FGM/C was an inherent part of the Kikuyu ethnic identity, and that the procedure was the essence of the Kikuyu institution. This support had enormous moral, social and religious implications, and meant that subsequently no Kikuyu man would marry a woman without FGM/C (Shell-Duncan \& Hernlund, 2000). FGM/C can be viewed as intertwined with ethnic identity and entrenched in social norms, and proponents of the ritual believe that any form of negativity, including eradication efforts and rejection of the procedure, is an attack against their culture (Jones et al., 2004). 


\section{Socio-economic status of women}

In the communities that support the practice of FGM/C, it is celebrated, and practitioners of the ritual view it as a joyful occasion and a ceremony that is essential for raising girls, while holding together the community and reinforcing its values and the boundaries of ethnicity (Abusharaf, 2006). The ceremonies ensure economic benefits for the practitioners through the services they offer to families (UNICEF, 2005). This is further entrenched within these communities as every family of an initiate is required to pay for the service in monetary or other forms, such as gifting livestock to the practitioner (UNICEF, 2005). In addition to the economic benefits, practitioners are afforded a revered social status within the community (Jones et al., 2004; UNICEF, 2005).

In these communities, economic security for women is derived from gendered roles of motherhood, for which one must first become a wife (Gruenbaum, 2001; Jones et al., 2004). For village women with little or no education, there are limited prospects of employment in the non-subsistence economy, and they must rely on their husbands for economic stability during reproductive years, to gain social status for old age, ensuring security and respect as they age (Denniston, 2006; Little, 2003). Jones and Ehiri (2004) argued that women who are not 'cut' usually remain unmarried, are viewed as immature, and are given the same status as an infant; therefore, they have no rights to any social status and become a symbol of dishonour for their families. Chege et al. (2001) explained that as an economic strategy, FGM/C comes with rewards and gifts for initiates of the procedure. Taking these factors into account, it is clear why parents abide by the traditional rules of societies that sustain the practice of $\mathrm{FGM} / \mathrm{C}$, and why they closely follow the rules of marriage, which in turn, sustain the practice of FGM/C (Gruenbaum, 2001).

According to Berggren (2005), female social pressure from older women within communities that practice FGM/C is a major issue for women who resist the procedure for their children. Traditional circumcisers are revered, and their expertise is sought by the community (Njue \& Askew, 2004a). The fact that FGM/C provides social status and is a means of income for medical practitioners as well as socio-economic insurance for traditional women has, in many cases, made it difficult for the law to be enforced, particularly in African countries (Berg \& Denison, 2013; Jones et al., 2004). Mackie and LeJeune (2009) stated that women are, interestingly, the supporters and enforcers of FGM/C in their role as practitioners, revealing how the two opposing ideologies of maternalism and paternalism can reinforce one another. In fact, the support by women for FGM/C has been described as the 'chief puzzle' (Makie \& LeJeune, 2009, p. 27) that leaves outsiders completely bewildered. Maternalism is further discussed later in the paper.

\section{HISTORY OF FGM/C}

The origins of FGM/C are reported to predate Christianity, Judaism and Islam (Elchalal, BenAmi, Gillis, \& Brzezinski, 1997; Morris, 1999)—both Morris and Elchalal and colleagues suggested that FGM/C has existed for over 5,000 years across different cultures, and was reportedly found in Egyptian mummies. Between 1470 and 1547 AD, Pietro Bembo, an Italian historiographer acclaimed for his accuracy, produced an extensive description of female genital cutting and modification in Africa, containing the first known description of infibulations (Johnsdotter, 2012). However, it is not clear how and where Bembo obtained this information, although it is speculated his descriptions of infibulations may have been obtained from Venetian sailors or Ethiopian delegates present at the Council of Florence in 1441 (Widstrand, 1965). Further, Burstow (1999) suggested that the first historical mention of FGM/C was made by Herodotus, the Greek historian, in $450 \mathrm{BC}$, and referred to other references made by Strabo (25 BC), Soramus (138 AD) and Aetius (502-575 AD). 
Although there have been suggestions that FGM/C was widely practiced among ancient Egyptians (Elchalal et al., 1997; Morris, 1999), other literature has suggested that there is no evidence of FGM/C in pre-dynastic or later times (Hastings, 1928). Whitehorn and colleagues (2002) argued that as part of the mummification procedure, embalmers removed tissues from the vulva to cover the anus, possibly to prevent sexual violation of the corpse. Alternatively, it has been posited that the absence of the tissue simply resulted from the deterioration of the corpse (Knight, 2001). Additionally, it has been argued that the embalming techniques in Egyptian mummies do not permit the gathering of evidence that can adequately confirm or refute FGM/C in this period (Johnsdotter, 2012; Meinardus, 1967; Seligman \& Ireland, 1913).

In ancient Rome, it was argued that rings were passed through the labia majora of slaves to prevent procreation (Mackie, 2000). Nour, Michels and Bryant (2006) reported that clitoridectomy was practiced for the treatment of painful menstruation and to curb masturbation in the US. To date, FGM/C is still popular and customarily a rite of passage for many ethnic communities of Sub-Saharan Africa and other minority groups and communities around the world (Lightfoot-Klein, 1989).

\section{TYPES OF FGM/C}

The WHO released an inter-agency joint statement in 2008 with a focus on the elimination of FGM/C (OHCHR, UNDP, UNESCO, UNHCR, \& UNIFEM, 2008). As a means to identify the different levels of severity in the presentation of the procedure, FGM/C was classified into four categories, referred to as Type I, Type II, Type III and Type IV. Type III was described as the most severe, while Type IV was described as merely symbolic and not a ritual (WHO, 1997). However, Obermeyer (2005) raised concerns regarding the inconsistencies presented in the information used about FGM/C, explaining that the challenges that occur as a result of language translation and comparison of FGM/C across cultures may create an overlap in the categorisation of the procedure, which may lead to inaccuracies in the way the typology of FGM/C is characterised. Although Obermeyer (2005) disputed some of the claims regarding the severity of FGM/C being overstated, it is necessary to note that all types of FGM/C may contribute to significant sexual and reproductive consequences for the health of women and girls, including but not limited to sexual inhibition and infertility (Denniston, 2006; Obermeyer, 2005).

\section{FGM/C Type I and Type II}

FGM/C Type I is subdivided into Type Ia and Type Ib (UNICEF, 2005). Type Ia is reported to be the intentionally removal of the hood of the clitoris, but this rarely occurs on its own (Obermeyer, 1999). Type Ib, which is more common, involves the removal of the clitoral hood and may also include the partial or complete removal of the clitoris together with that of the prepuce, resulting in the procedure known as a clitoridectomy (Toubia \& Izett, 1998). FGM/C Type II involves partial removal of the clitoris and labia minora and may include the partial excision of the labia majora (UNICEF, 2005). Type II is also referred to as excision, as the clitoris may be held between the thumb and the finger and then amputated with a sharp object, after which bleeding is traditionally stopped via the application of ashes or herbs (Obermeyer, 2005).

\section{FGM/C Type III}

FGM/C Type III is also known as infibulation, and involves the removal of all external genitalia, followed by fusion of the wound, traditionally with foreign material such as cat gut, thorns or surgical threads (Abdulcadir, Margairaz, Boulvain, \& Irion, 2011; Momoh, 2004). Traditionally, a small twig or similar object is inserted into the wound before it fuses together to create a small hole, reportedly $2-3 \mathrm{~mm}$, for the passing of urine and menstrual flow. At a later time, it is 
usually expanded with a knife before intercourse or child birth in the procedure known as deinfibulation (Abdulcadir et al., 2011). Type III is reportedly the most severe of all FGM/C procedures, and has severe consequences for sexual functioning and reproductive health of women, often with severe obstetric outcomes for infants and mothers (Penna, Fallani, Fambrini, Zipoli, \& Marchionni, 2002). In a study conducted in Norway, it was revealed that infibulated women were at higher risk of obstetric or birth complications compared with those who had not been infibulated, and healthcare professionals experienced the delivery care of infibulated women to be challenging, technically, emotionally and ethically (Johansen, 2006).

\section{FGM/C Type IV}

FGM/C Type IV involves pricking, piercing, incising and scraping the clitoris to let blood; this symbolises the ritual of FGM/C, particularly among communities where FGM/C is criminalised (Bagnol \& Mariano, 2008; Newland, 2006). It may also include the pulling or stretching of the clitoris to elongate it, which is prevalent particularly in Uganda (Khau, 2012; Tamale, 2006). Other practices include cauterisation of the clitoris and the surrounding tissues with heated metals such as the tip of a blunt knife or broken glass (United Nations, 2008). Introduction of herbs to corrode and cause bleeding in the vagina with the intention to tighten it, known as 'dry sex', has also been documented (Martin Hilber et al., 2012). In some instances, Type IV is more symbolic than physical, and occurs as a replacement for other more severe types of FGM/C (Njue \& Askew, 2004a; Yoder \& Khan, 2008).

Berggren and colleagues (2006) reported that Type IV is likely to be practiced among communities that fear prosecution, especially migrant communities in Western countries. Clitoral incisions on infants and young children have been reported (Budiharsana, 2004), as has scraping of the clitoris (Newland, 2006). This is symbolic and may occur to substitute for the major forms of FGM/C where circumcision ceremonies may not be possible, either because of fear of explicit violation of the law or prevention of complete genital damage by parents, who may still yield to pressure from the children's extended family members to undergo circumcision (Mwenda, 2008). However, all four types of FGM/C are reported to have adverse physical, social, sexual and psychological impacts, including the risk of contracting HIV, as discussed later in the paper (Brady, 1999; Diouf, 2013; UNICEF, 2005).

\section{PREVALENCE OF FGM/C}

An estimated 200 million women and girls globally have undergone the FGM/C procedure (WHO, 2018). According to UNICEF (2013), the highest percentage of women and girls who have undergone FGM/C reside in Africa, ranging from 1\% in Cameroon and $4 \%$ in Ghana and Togo to above 91\% in Egypt and 98\% in Somalia. In Europe, it is estimated that half a million women and girls are living with FGM/C (Van Baelen, Ortensi, \& Leye, 2016).This is due to the mobility of women and girls from geographical regions with a high prevalence of FGM/C (Evans et al., 2019; Ogunsiji, 2015).

In Australia, there is a paucity of research and literature around FGM/C. It is therefore difficult to determine prevalence in Australia, as it is typical for women living with FGM/C to arrive post the procedure (Knight, Hotchin, Bayly, \& Grover, 1999).

Yoder and Khan (2008) speculated that FGM/C has been practiced in Australia since 1994. Further, it has been suggested that the increase of migrants into Australia from countries where FGM/C is practiced is an indication that prevalence may be increasing in Australia (Mathews, 2011). Statistical analysis indicates that Australia received 38,299 migrants from 11 African countries where FGM/C is highly prevalent (Burke, 2010), including Sudan $(24,082)$, 
Egypt $(6,258)$, Somalia $(2,736)$ and Ethiopia $(5,223)$, with the remainder from other African nations ( [DIAC], 2009).

In 2010, the Melbourne Royal Hospital reported that it had seen 600-700 women living with FGM/C (Bourke, 2010). However, Matthews (2011) highlighted the impossibility of precisely determining the prevalence of FGM/C in Australia because of the secretive and private nature of its occurrence in contrast to symbolic public ceremonies in countries where the procedure is customary. Ogunsiji, Wilkes and Jackson (2007) suggested that the secrecy that shrouds the practice of FGM/C stems from stigma and fear of prosecution that may follow if it is performed on children in Australia.

In Asia, FGM/C has been reported in South East and Central Asia, Afghanistan, Pakistan and India (Khalid et al., 2013; Magoha \& Magoha, 2000). FGM/C is reported to be highly prevalent in Malaysia and Indonesia, with Types I and IV the most common (Isa, Shuib, \& Othman, 1999). Dahlui, Wong and Choo (2012) reported that religion was given by $84 \%$ of respondents in Malaysia as the motivator for practising FGM/C, followed by hygiene (41\%) and cultural practice (32\%); they estimated that $62-90 \%$ of Muslim women in Malaysia have undergone FGM/C. In Indonesia, mass mutilation ceremonies have been reported on Prophet Mohammed's birthday, and studies undertaken in 2003 and 2010 found that $60 \%$ of young Muslim girls had undergone the procedure between infancy and the age of 9 years (Budiharsana, 2004). At 90\%, the prevalence of FGM/C in Indonesia is the highest of any Muslim country, with Types I and IV the most commonly performed (Budiharsana, 2004).

Bjälkander, Grant, Berggren, Bathija and Almroth (2013) suggested that reported prevalence estimates vary by source, and much of the data are obtained by verbal surveys and self-report, as it is uncommon for clinical examinations to occur, as it is taboo to discuss sexual matters in most cultures that practice FGM/C. Additionally, Yoder and Khan (2008) stated that scholars can only rely on the assumption that women answer truthfully questions regarding their experiences of FGM/C. Indeed, FGM/C is primarily performed on children (UNICEF, 2005), bringing into question the validity of survey results because of the potential for underreporting (Bjälkander et al., 2013). It is difficult, therefore, to state with certainty the prevalence of FGM/C not only across Africa, but in other FGM/C-prevalent regions of the world (Elmusharaf, Elhadi, \& Almroth, 2006; Rahman \& Toubia, 2000).

\section{CONSEQUENCES OF FGM/C}

Almroth, Bedri et al. (2005) reported that there are no clinical studies that have documented the consequences of FGM/C, and the body of available literature only documents the results of survey-based research; however, anecdotal evidence and accounts of the consequences of FGM/C show a clear connection between the procedure and adverse sexual and reproductive health outcomes (Balk, 2000). Immediate and long-term sexual and reproductive health conditions have been reported in women with FGM/C, although the severity of these conditions is reported to be dependent on the extent or type of procedure.

El-Defrawi, Lotfy, Dandash, Refaat and Eyada (2001) found that FGM/C creates long-term health conditions such as sexual dysfunction, difficulties in achieving orgasm and reduction of sexual desire; however, it was noted that this study was not representative of the general population, as the research participants were already patients of a psychosexual clinic. There is a lack of evidence or documentation confirming that all women living with FGM/C suffer all or any of the consequences as detailed above. Further, Obermeyer (2005) argued that although FGM/C is associated with sexual and reproductive complications, there is no documented evidence to support these hypotheses of complications as a result of FGM/C. Obermeyer 
further argued that the available evidence on the sexual and reproductive health consequences of FGM/C should be viewed in light of global trends and prevalence as the medicalisation of the practice has progressively increased in recent years

\section{FGM/C and female sexual dysfunction}

Raina et al. (2007) defined female sexual dysfunction as a disorder of arousal, orgasm, sexual desire and sexual pain, which may result in significant personal distress. Sexual function after FGM/C is cited as a very important issue, but has not been as well researched as male sexual function after circumcision (Alsibiani \& Rouzi, 2010; Watson, 2005). Obermeyer (2003) reviewed studies on the sexual function of women with FGM/C, and found that much of the existing research had many limitations, and hence could not confidently report that the presence of FGM/C affected a woman's sexual functioning. For example, she cited discrepancies in the study methodologies, including research frameworks that could not achieve authentic data and information on the impact of FGM/C on the sexuality of women. Further, she highlighted that the cultural and social contexts of the research and the questionnaires used were particularly biased (Obermeyer, 2005).

However, Rymer and O'Flynn (2013) conducted a study in a women's wellness clinic in Guy's Hospital London, with a hypothesis that women who had undergone FGM/C had low sexual quality of life compared with those who had not had the procedure. The study demonstrated that women living with FGM/C had a low sexual quality of life, and this was particularly severe in those who had undergone Type III (Rymer \& Flynn 2013). Momoh (2004) investigated sexual dysfunction in women living with FGM/C, and found that this group included women meeting the criteria for dyspareunia, anorgasmia, vaginal dryness, apareunia and decreased sexual desire. Additionally, a study by El-Defrawi and colleagues (2001) identified that $78 \%$ of women living with FGM/C reported experiencing dyspareunia. Another cross-sectional study on the sexual function of Egyptian women living with FGM/C reported higher rates of anorgasmia and significant impacts on vaginal lubrication, arousal and desire (Anis, Aboul Gheit, Awad, \& Saied, 2012).

Alsibiani and Rouzi (2010) found that FGM/C negatively affects the sexuality of women, and that severity of sexual dysfunction is significant in those with Type III of the procedure. Berg and Dennison (2012) carried out a meta-analysis that revealed that women with any type of FGM/C were 1.7 times more likely to experience dyspareunia and 2.5 times more likely to report a lack of sexual desire as compared with those without FGM/C. Another study found that women with FGM/C had difficulties in achieving vaginal lubrication, arousal, orgasm and sexual satisfaction, including sexual pain on vaginal penetration, as compared with women who had not experienced FGM/C (Abd El-Naser, Farouk, El-Nashar, \& Mostafa, 2011). These support the findings of a study by El-Defrawi and colleagues (2001) that found that FGM/C negatively affects women's psychosexual life, resulting in the problems discussed above, as well as vaginal dryness and painful intercourse. Abdi El-Naser and colleagues (2011) suggested that female sexual dysfunction occurred even among women with the simplest forms of FGM/C (Types I and IV). However, Jones and colleagues suggested that these types of studies were potentially confounded by attitudes towards female sexuality and interpretations of sexual pleasure among the target group of immigrants from countries that practiced the procedure.

Despite the difficulties in researching the negative impacts that FGM/C may have on the sexuality of women, there is substantial research and literature detailing the sexual consequences associated with the procedure. This information seems to support the belief that FGM/C has an adverse impact on the sexual functioning of women, irrespective of the type performed (Abd El-Naser et al., 2011). 


\section{FGM/C and sexual and reproductive health outcomes}

According to the WHO (2006), the reproductive consequences of FGM/C can be numerous, including permanent genital trauma, infections, infertility and difficult labour during childbirth. Additionally, Berg and Underland (2013) reported that women may experience chronic pelvic infections, urinary tract infections because of poor flow of menstruation, and accumulation and retention of urine in the vaginal canal and the urethra as a result of cysts and keloid scarring. This section discusses the link between FGM/C, reproductive infections and transmission of HIV, and impacts on the fertility of couples living with FGM/C. Genital trauma resulting from $\mathrm{FGM} / \mathrm{C}$ can lead to partial or complete occlusion of the vagina, especially where keloid scarring occurs, and subsequent bleeding during intercourse, which can potentially lead to infertility in couples (Almroth, 2001; Nour, 2006). Penile abrasions are reported to occur in men attempting intercourse with infibulated women, making it difficult for couples to engage in vaginal intercourse; some resort to anal intercourse, which cannot result in pregnancy (Diouf, 2013; Nour et al., 2006). It has been reported that some women with FGM/C avoid sexual intercourse all together because of fear of sexual pain, resulting in unconsummated marriages (Garvey-Graham, 2008). De-infibulation may be necessary to successfully facilitate sexual intercourse, when penile de-infibulation (i.e. de-infibulation through intercourse) fails (Larsen \& Okonofua, 2002). This can create further genital trauma, making sexual intercourse even more difficult and creating extra barriers for couples with FGM/C to become pregnant (Reyners, 2004).

Pelvic inflammatory diseases caused by non-sterile conditions during the FGM/C procedure may result in tubal occlusion, causing infertility (Nour et al., 2006). Berg and colleagues (2012) stated that women living with FGM/C may experience obstetric complications including difficult pregnancy and prolonged labour, which can increase the need to intervene during the birthing process (e.g. caesarean section or episiotomy); this is especially the case for women with infibulations. Although deaths have been reported as a result of FGM/C procedures, there is no evidence to support these claims and it is unknown if these deaths are common or rare (Jones et al., 2004). Berggren and colleagues (2004) suggested that pregnant women with infibulations have higher mortality rates than those without the procedure, while neonates born to women with FGM/C are more likely to suffer asphyxia than those whose mothers have no FGM/C. However, Obermeyer (2005) argued that there is a lack of clear definitions of key concepts such as pain during intercourse, sexual pleasure and prolonged labour, and how they were measured, to inform research. Indeed, there is a need for clinical research into the experiences of women with FGM/C using methodologies that ensure representativeness in both the sample and control groups.

\section{FGM/C and HIV transmission}

Diof and Nour (2013) stated that the adverse effects of Type I, Type II and Type III FGM/C can be both short and long term, and potentially increase the risk factors for HIV transmission because of use of non-sterile instruments during the procedure. Previously, Wakabi (2007) documented how surgical equipment is traditionally used numerous times on more than one initiate during the FGM/C procedure without being sterilised, increasing the risk of HIV and other blood-borne viruses being transmitted. Additionally, Yount (2007) argued that excessive bleeding is a complication during the FGM/C procedure that can increase the need for medical attention (i.e. a blood transfusion); this may again increase the risk of HIV transmission.

Men who are married to women living with FGM/C may experience difficult intercourse, which has been reported as a factor leading to extramarital relationships with women without FGM/C, again increasing the risk of an exposure to HIV (Almroth, 2001; Osinowo \& Taiwo, 2003). Nour and colleagues (2006) reported that extramarital sex has been shown in many 
studies to increase the risk of the transmission of sexually transmitted infections including HIV. However, Diouf and Nour (2013) explained that although the link between FGM/C and HIV in couples with FGM/C has been hypothesised, there is a lack of evidence to substantiate this, in part because of the unclear and inappropriate methods of data collection and analysis in the overall FGM/C studies to date.

\section{MEDICALISATION OF FGM/C}

The medicalisation of FGM/C refers to any form of FGM/C being performed by healthcare providers, whether in private or public facilities, in the home or any other place where it may occur, in contrast to the traditional circumcision ceremony, which is usually ritualised and surrounded by public celebrations (Kimani \& Duncan, 2018; Shell-Duncan \& Hernlund, 2000; UNICEF, 2013). In Kenya, for example, the medicalisation of FGM/C has become common among holidaymakers living in Western countries who originate from this country. It is common among the Bagusii and the Kuria in the west of the country, where FGM/C is highly prevalent; Njue and Askew (2004b) reported that it has become common for nurses, midwives and even medical doctors to perform the procedure after consultations with a child's parents. Shell-Duncan (2001) argued that the medicalisation of FGM/C was conceptualised in an effort to reduce health risks associated with traditional 'circumcision'. Specifically, Shell-Duncan stated that the medicalisation of FGM/C can prevent and curb the transmission of HIV (and other blood-borne viruses) in practising communities. As previously mentioned, it has been hypothesised that FGM/C increases the risk of HIV transmission because of the shared use of soiled cutting devices among those being 'cut' and the non-sterile environment in which FGM/C occurs (Diof \& Nour, 2013). Additionally, it has been suggested that the medicalisation of FGM/C assists to prevent extensive bleeding, pain and potential death due to shock among children (Derby, 2004; Serour, 2013).

Kimani and Shell-Duncan (2018) argued that the medicalisation of FGM/C can lead to the reduction of complications resulting from the procedure by providing a safer practice, which is especially important in communities where the abandonment of FGM/C is not likely because of cultural practices that require women and girls to undergo the procedure. Further, ShellDuncan (2001) compared the benefits of the medicalisation of FGM/C to those found as a result of the introduction of needle and syringe exchange programs for illicit drug users, in that this preventative strategy has been seen globally to reduce the incidence of HIV (and other bloodborne virus) transmissions. However, the medicalisation of FGM/C raises moral questions as to whether it is a measure to protect the sexual and reproductive health of girls and women, or an imperialistic promotion of a dangerous practice (Pearce \& Bewley, 2014; Serour, 2013).

In Kenya, government prosecution of parents and circumcisers has seen a rise in the medicalisation of $\mathrm{FGM} / \mathrm{C}$, as this is a more private procedure than the traditional mass circumcision that occurs ceremonially in public (Njue \& Askew, 2004; Shell-Duncan \& Hernlund, 2000). According to the WHO (2008), with the rise in the medicalisation of FGM/C, it is becoming more difficult to eradicate the procedure. The minimisation of complications during and after the procedure raises questions as to whether the medicalisation of FGM/C reduces harm or perpetuates an extremely dangerous practice (Broussard, 2008; Hilber et al., 2012).

Despite the increase in the medicalisation of $\mathrm{FGM} / \mathrm{C}$, the procedure is still predominantly performed by traditional circumcisers (Little, 2003; Shell-Duncan, 2015; UNICEF, 2005). However, the validity of the concept of the medicalisation of FGM/C is questionable on the basis that the medicalisation of FGM/C in Western society is confined to minority groups such as migrant communities from Sub-Saharan Africa and other FGM/C-practising countries who 
may seek the services of healthcare professionals for their children and re-infibulation of women after child birth (Berggren et al., 2004). The WHO (2008) issued a joint statement against the medicalisation of FGM/C on the basis that it condones and perpetuates a harmful practice, further stating that the medicalisation of FGM/C is a dangerous and criminal practice, requiring strategies to stop healthcare providers from carrying out this procedure.

\section{CONCLUSION}

FGM/C is a practice that violates the sexuality and overall health and wellbeing of women and girls. A campaign to bring awareness to the entire global community must remain ceaseless until the procedure is ended. Currently, procedures continue unabated in countries that traditionally and ritually perform FGM/C on children. Medicalisation could indicate a shift from traditional practice to support its continuation. A call is made in this paper for practitioners of $\mathrm{FGM} / \mathrm{C}$ to be educated on the consequences of the practice and punitive measures meted out to those who continue to promote FGM/C.

\section{ACKNOWLEDGEMENT}

We acknowledge Curtin University's School of Public Health where the original thesis that informed this paper was submitted. We also recognise Mr Matt Tilley of Curtin University's School of Public Health who supervised the original thesis.

\section{References}

Abd El-Naser, T., Farouk, A., El-Nashar, A. E.-R., \& Mostafa, T. (2011). Sexual side effects of female genital mutilation/cutting may be type dependent: a hospital-based study. Kasr Al-Aini Journal of Obstetrics \& Gynecology, 1(2), 65-74.

Abdulcadir, J., Irion, O., \& de Tejada, B. M. (2015). Female genital mutilation/cutting type IV in Cambodia: a case report. Clinical case reports, 3(12), 979.

Abusharaf, R. M. (2006). Introduction: The custom in question. Female circumcision: Multicultural perspectives, 125 .

Almroth, L., Bedri, H., El Musharaf, S., Satti, A., Idris, T., Hashim, M. S. K., .. Bergström, S. (2005a). Urogenital complications among girls with genital mutilation: a hospital-based study in Khartoum. African journal of reproductive health, 118-124.

Almroth, L., \& Elmusharaf, S. (2007). Genital mutilation of girls.

Almroth, L., Elmusharaf, S., El Hadi, N., Obeid, A., El Sheikh, M. A., Elfadil, S. M., \& Bergström, S. (2005b). Primary infertility after genital mutilation in girlhood in Sudan: a case-control study. The Lancet, 366(9483), 385-391.

Anis, T. H., Aboul Gheit, S., Awad, H. H., \& Saied, H. S. (2012). Effects of Female Genital Cutting on the Sexual Function of Egyptian Women. A Cross-Sectional Study. The journal of sexual medicine, 9(10), 2682-2692.

Balk, D. (2000). To marry and bear children? The demographic consequences of infibulation in Sudan. Female 'circumcision'in Africa. Culture, controversy and change. London: Lynne Rieneuer Publishers, 55-71.

Barstow, D. G. (1999). Female genital mutilation: the penultimate gender abuse. Child abuse \& neglect, 23(5), 501510.

Berer, M. (2007). It's female genital mutilation and should be prosecuted. Bmj, 334(7608), 1335-1335.

Berg, R. C., \& Underland, V. (2013). The obstetric consequences of female genital mutilation/cutting: a systematic review and meta-analysis. Obstetrics and gynecology international.

Berggren, V., Salam, G. A., Bergström, S., Johansson, E., \& Edberg, A.-K. (2004). An explorative study of Sudanese midwives' motives, perceptions and experiences of re-infibulation after birth. Midwifery, 20(4), 299-311.

Bibbings, L. S. (2006). Female genital mutilation: whose problem, whose solution?: Mutilation or modification? Bmj, 333(7561), 259-260.

Bjälkander, O., Grant, D. S., Berggren, V., Bathija, H., \& Almroth, L. (2013). Female genital mutilation in Sierra Leone: forms, reliability of reported status, and accuracy of related demographic and health survey questions. Obstetrics and gynecology international, 2013. 
Bourke, E. (2010). Female circumcision happening in Australia. ABC News, 6.

Boyle, E. H., \& Corl, A. C. (2010). Law and culture in a global context: Interventions to eradicate female genital cutting. Annual Review of Law and Social Science, 6, 195-215.

Dahlui, M., Wong, Y., \& Choo, W. (2012). Female circumcision (FC) in Malaysia: Medicalization of a religious practice. Paper presented at the International Journal of Behavioral Medicine.

Davis, D. S. (2010). Ritual genital cutting of female minors. Pediatrics, 125(5), 1088-1093. doi:10.1542/peds.20100187

Diouf, K. N. N. (2013). Female Genital Cutting and HIV Transmission: Is There an Association? AJI American Journal of Reproductive Immunology, 69, 45-50.

El-Defrawi, M. H., Lotfy, G., Dandash, K. F., Refaat, A. H., \& Eyada, M. (2001). Female genital mutilation and its psychosexual impact. Journal of sex \& marital therapy, 27(5), 465-473.

Elmusharaf, S., Elhadi, N., \& Almroth, L. (2006). Reliability of self reported form of female genital mutilation and WHO classification: cross sectional study. Bmj, 333(7559), 124.

Essen, B., \& Johnsdotter, S. (2004). Female genital mutilation in the West: traditional circumcision versus genital cosmetic surgery. Acta Obstet Gynecol Scand, 83(7), 611-613. doi:10.1111/j.0001-6349.2004.00590.x

Evans, C., Tweheyo, R., McGarry, J., Eldridge, J., Albert, J., Nkoyo, V., \& Higginbottom, G. (2019). Improving care for women and girls who have undergone female genital mutilation/cutting: qualitative systematic reviews. Health Services and Delivery Research, 7(31).

Fahmy, A., El-Mouelhy, M. T., \& Ragab, A. R. (2010). Female genital mutilation/cutting and issues of sexuality in Egypt. Reproductive health matters, 18(36), 181-190.

Garvey-Graham, A. M. (2008). Midwives' Experiences of Caring for Women During Childbirth Who Have Undergone Female Genital Mutilation: An Interpretative Study.

Gibeau, A. M. (1998). Female genital mutilation: when a cultural practice generates clinical and ethical dilemmas. $J$ Obstet Gynecol Neonatal Nurs, 27(1), 85-91. doi:10.1111/j.1552-6909.1998.tb02595.x

Gonzales-Alabastro, C., Eilber, K. S., Anger, J. T., \& Berman, J. R. (2019). Female Cosmetic Genital Reconstruction: a Review of Current Trends, Treatments, and Techniques. Current sexual health reports, 11(1), 44-51. doi:10.1007/s11930-019-00191-1

Gruenbaum, E. (2006). Sexuality issues in the movement to abolish female genital cutting in Sudan. Medical Anthropology Quarterly, 20(1), 121-138.

Hilber, A. M., Kenter, E., Redmond, S., Merten, S., Bagnol, B., Low, N., \& Garside, R. (2012). Vaginal practices as women's agency in sub-Saharan Africa: a synthesis of meaning and motivation through meta-ethnography. Social science \& medicine, 74(9), 1311-1323.

Hosken, F. (1979). The Hosken report: genital and sexual mutilation of females.

Idowu, A. A. (2008). Effects of female genital-mutilation on human rights of women and female children: The Nigerian situation. Research Journal of International Studies, 8, 13-26.

Isa, A. R., Shuib, R., \& Othman, M. S. (1999). The practice of female circumcision among Muslims in Kelantan, Malaysia. Reproductive health matters, 7(13), 137-144.

Johansen. (2006). Care for infibulated women giving birth in Norway: an anthropological analysis of health workers' management of a medically and culturally unfamiliar issue. Medical Anthropology Quarterly, 20 (4), 516.

Johansen, Ziyada, M. M., Shell-Duncan, B., Kaplan, A. M., \& Leye, E. (2018). Health sector involvement in the management of female genital mutilation/cutting in 30 countries. BMC Health Serv Res, 18(1), 240. doi:10.1186/s12913-018-3033-x

Jones, S. D., Ehiri, J., \& Anyanwu, E. (2004). Female genital mutilation in developing countries: an agenda for public health response. European Journal of Obstetrics \& Gynecology and Reproductive Biology, 116(2), 144-151.

Kimani, S., \& Shell-Duncan, B. (2018). Medicalized female genital mutilation/cutting: contentious practices and persistent debates. Current sexual health reports, 10(1), 25-34.

Knight, R., Hotchin, A., Bayly, C., \& Grover, S. (1999). Female Genital Mutilation-Experience of The Royal Women's Hospital, Melbourne. Australian and New Zealand journal of obstetrics and gynaecology, 39(1), 50-54. 
Kolawole, O. M. (2011). Female Genital Mutilation: When Culture and Human Rights Collide: an Analysis of Asylum and Refugee Law. Webster University, London.

Larsen, U., \& Okonofua, F. E. (2002). Female circumcision and obstetric complications. International Journal of Gynecology \& Obstetrics, 77(3), 255-265. doi:http://dx.doi.org/10.1016/S0020-7292(02)00028-0

Leval, A., Widmark, C., Tishelman, C., \& Maina Ahlberg, B. (2004). THE ENCOUNTERS THAT RUPTURE THE MYTH: CONTRADICTIONS IN MIDWIVES'DESCRIPTIONS AND EXPLANATIONS OF CIRCUMCISED WOMEN IMMIGRANTS'SEXUALITY. Health care for women international, 25(8), 743-760.

Lightfoot-Klein, H. (1989). The sexual experience and marital adjustment of genitally circumcised and infibulated females in the Sudan. Journal of sex research, 26(3), 375-392.

Livermore, L., Monteiro, R., \& Rymer, J. (2007). Attitudes and awareness of female genital mutilation: A questionnaire-based study in a Kenyan hospital. Journal of Obstetrics and Gynaecology, 27(8), 816-818.

Mackie, G. (2000). Female genital cutting: the beginning of the end. Female" circumcision" in Africa: culture, controversy, and change. Boulder, Colorado, Lynne Rienner, 253-282.

Mackie, G., \& LeJeune, J. (2009). Social dynamics of abandonment of harmful practices: a new look at the theory. Special Series on Social Norms and Harmful Practices, Innocenti Working Paper(2009-06), 20.

Martin Hilber, A., Kenter, E., Redmond, S., Merten, S., Bagnol, B., Low, N., \& Garside, R. (2012). Vaginal practices as women's agency in Sub-Saharan Africa: A synthesis of meaning and motivation through meta-ethnography. Social Science \& Medicine, 74(9), 1311-1323. doi:http://dx.doi.org/10.1016/j.socscimed.2011.11.032

Mathews, B. (2011). Female genital mutilation: Australian law, policy and practical challenges for doctors. Medical Journal of Australia, 194(3), 139-141.

Mitike, G., \& Deressa, W. (2009). Prevalence and associated factors of female genital mutilation among Somali refugees in eastern Ethiopia: a cross-sectional study. BMC public health, 9(1), 264.

Momoh, C. (2004). Female genital mutilation. Current Opinion in Obstetrics and Gynecology, 16(6), 477-480.

Momoh, C. (2005). Female Genital Mutilation. Boca Raton: CRC Press LLC

Newland. (2006). Female circumcision: Muslim identities and zero tolerance policies in rural West Java. Paper presented at the Women's studies international forum.

Newland, L. (2006). Female circumcision: Muslim identities and zero tolerance policies in rural West Java. Women's Studies International Forum Women's Studies International Forum, 29(4), 394-404.

Njue, C., \& Askew, I. (2004a). Medicalization of female genital cutting among the Abagusii in Nyanza Province, Kenya: Washington DC, Population Council Frontiers in Reproductive Health.

Njue, C., \& Askew, I. (2004b). Medicalization of female genital cutting among the Abagusii in Nyanza Province, Kenya.

Nour, N. M., Michels, K. B., \& Bryant, A. E. (2006). Defibulation to treat female genital cutting: effect on symptoms and sexual function. Obstetrics \& Gynecology, 108(1), 55-60.

Nussbaum, M. C. (1999). Judging other cultures: The case of genital mutilation. Sex and Social Justice. MC, 119-129.

Obermeyer, C. M. (1999). Female genital surgeries: the known, the unknown, and the unknowable. Medical Anthropology Quarterly, 13(1), 79-106.

Obermeyer, C. M. (2003). The health consequences of female circumcision: science, advocacy, and standards of evidence. Medical Anthropology Quarterly, 17(3), 394-412.

Ogunsiji, O. (2015). Female genital mutilation (FGM): Australian midwives' knowledge and attitudes. Health care for women international, 36(11), 1179-1193.

OHCHR, U., UNDP, U., UNESCO, U., UNHCR, U., \& UNIFEM, W. (2008). Eliminating female genital mutilation: An interagency statement. Geneva: WHO.

Pearce, A. J., \& Bewley, S. (2014). Medicalization of female genital mutilation. Harm reduction or unethical? Obstetrics, Gynaecology \& Reproductive Medicine, 24(1), 29-30.

Porterfield, S. P. (2006). Female genital cutting. The Journal for Nurse Practitioners, 2(4), 256-260.

Rahman, A., \& Toubia, N. (2000). Female genital mutilation: A practical guide to worldwide laws \& policies: Zed Books.

Rahman, A., \& Toubia, N. (2001). Female genital mutilation: A guide to worldwide laws and policies: Zed Books. 
Raina, R., Pahlajani, G., Khan, S., Gupta, S., Agarwal, A., \& Zippe, C. D. (2007). Female sexual dysfunction: classification, pathophysiology, and management. Fertility and sterility, 88(5), 1273-1284.

Reyners, M. (2004). Health consequences of female genital mutilation. Reviews in Gynaecological Practice, 4(4), 242-251. doi:10.1016/j.rigp.2004.06.001

Roy, K. (2013). Female genital cutting in Indonesia; a field study. Islamic Relief Canada

Rushwan, H. (2013). Female genital mutilation: A tragedy for women's reproductive health. African Journal of Urology, 19(3), 130-133.

Rymer, J., \& O'Flynn, N. (October 01, 2013). Female genital mutilation: Everyone's problem. British Journal of General Practice, 63, 615, 515-516.

Serour, G. (2013). Medicalization of female genital mutilation/cutting. African Journal of Urology, 19(3), $145-149$.

Shaw, D., Lefebvre, G., Bouchard, C., Shapiro, J., Blake, J., Allen, L., \& Cassell, K. (2013). Female genital cosmetic surgery. J Obstet Gynaecol Can, 35(12), 1108-1112. doi:10.1016/s1701-2163(15)30762-3

Sheldon, S., \& Wilkinson, S. (1998). Female genital mutilation and cosmetic surgery: regulating non-therapeutic body modification. Bioethics, 12(4), 263-285.

Silverman, E. K. (2004). Anthropology and circumcision. Annual Review of Anthropology, $\quad$ 419-445.

Smith, C. (2011). Who Defines" Mutilation"? Challenging Imperialism in the Discourse of Female Genital Cutting. Feminist Formations, 25-46.

Thomas, L. (2000). Ngaitana (I will circumcise myself)": Lessons from colonial campaigns to ban excision in Meru, Kenya. Female "circumcision" in Africa: Culture, controversy, and change, London, The United Kingdom: Lynne Rienner Publishers Inc, 129-150.

Toubia, N. (1994). Female circumcision as a public health issue. New England Journal of Medicine, 331(11), 712716.

UNICEF. (2005). Female genital mutilation/cutting : a statistical exploration 2005. New York: United Nations Children's Fund.

United Nations, C. o. H. R. J. U. N. P. o. H. I. V. A. U. N. D. P. (2008). Eliminating female genital mutilation : an interagency statement OHCHR, UNAIDS, UNDP, UNECA, UNESCO, UNFPA, UNHCHR, UNICEF, UNIFEM, WHO. Geneva: World Health Organization.

Van Baelen, L., Ortensi, L., \& Leye, E. (2016). Estimates of first-generation women and girls with female genital mutilation in the European Union, Norway and Switzerland. The European Journal of Contraception \& Reproductive Health Care, 21(6), 474-482.

Varol, N., Turkmani, S., Black, K., Hall, J., \& Dawson, A. (2015). The role of men in abandonment of female genital mutilation: a systematic review. BMC public health, 15(1), 1034.

WHO, W. H. O. (2009). Women and health: today's evidence tomorrow's agenda: World Health Organization.

Widstrand, C. G. s. B. P. H. N. A. (1965). Development and adult education in Africa. Uppsala: Scandinavian Institute of African Studies.

Yoder, P. S., \& Khan, S. (2008). Numbers of women circumcised in Africa: The production of a total.

Zurynski, Y., Phu, A., Sureshkumar, P., Cherian, S., Deverell, M., \& Elliott, E. J. (2017). Female genital mutilation in children presenting to Australian paediatricians. Archives of disease in childhood, 102(6), 509-515. 